6. Kavita Mundey, Susan Benloucif, Krisztina Harsanyi, Margarita L. Dubocovich; Phyllis C. Zee1 Phase-Dependent Treatment of Delayed Sleep Phase Syndrome with Melatonin SLEEP. 2005. Vol. 8(10). P. 1271-1278

DOI https://doi.org/10.30525/978-9934-26-038-4-47

\title{
ДИНАМІКА ТОТАЛЬНИХ І ПОЗДОВЖНІХ РОЗМІРІВ ТІЛА У ДІВЧАТОК ПУБЕРТАТНОГО ПЕРІОДУ ОНТОГЕНЕЗУ
}

\author{
Сарафинюк Л. А. \\ доктор біологічних наук, професор, \\ завідувач кафедри фізичного виховання \\ та лікувальної фізичної культури \\ Вінницький національний медичний університет імені М. І. Пирогова \\ м. Вінниця, Украӥна \\ Сарафинюк П. В. \\ кандидат біологічних наук, \\ дочент кафедри біології \\ Вінницький державний педагогічний університет \\ імені Михайла Коиюбинського \\ м. Вінниця, Украӥна \\ Хапіцька О. П. \\ кандидат медичних наук, \\ доцент кафедри внутрішньої медицини № 3 \\ Вінницький національний медичний університет імені М. І. Пирогова \\ м. Вінниця, Украӥна \\ Лежньова О. В. \\ кандидат медичних наук, \\ доцент кафедри фізичного виховання та лікувальної фізичної культури \\ Вінницький начіональний медичний університет імені М. І. Пирогова \\ м. Вінниця, Украӥна
}

Гармонійність розвитку організму в дитячому, підлітковому, юнацькому віці багато в чому визначає подальше життя і долю жінки як в медичному, так і в соціальному аспектах $[1,2]$. Адже в даний час майже у кожного третього підлітка виявляються «слабкі ланки» в певних системах організму, які неадекватно реагують на фізичні наванта- 
ження [3]. Гармонійність фізичного розвитку служить результатом фізичних тренувань, що сприяють повноті реалізації спадкових задатків і свідчать про необхідність адекватного рухового виховання в період зростання і розвитку жіночого організму.

За результатами багатьох досліджень встановлено, що фактори навколишнього середовища, соціально-економічні умови, характер харчування, рівень медичної освіти суспільства та доступ до профілактичної медичної допомоги, впливають на початок та перебіг статевого дозрівання $[3,4,5]$. У дівчаток пубертат супроводжується фізичними та психо-емоційними змінами, що спрямовані на збереження та розвиток однієї з основних фізіологічних функцій жіночого організму - фертильності. Вік, у якому дівчата досягають пубертатну представляє значний інтерес для різних сфер медицини та науки в цілому, торкається проблем профілактики та ранньої діагностики у практичній медичній діяльності і $є$ предметом багатьох наукових досліджень щодо збереження та розвитку репродуктивного потенціалу $[6,7,8]$. Порушення статевого розвитку у дівчаток входить до трійки найбільш розповсюджених розладів ендокринної системи серед тих ,що вперше діагностуються первинною ланкою медичної системи, i, виправдано, залишаються основною причиною занепокоєння батьків [3]. Але необхідно зазначити, що однозначної думки у сучасних науковців стосовно основних тенденцій фізичного розвитку, а особливо в межах пубертатного періоду онтогенезу, немає.

Метою дослідження було вивчення розмірів тіла у дівчаток пубертатного періоду онтогенезу.

Нами було обстежено 106 школярок 5-8 класів загальноосвітніх шкіл м. Вінниці. 3 метою визначення біологічного віку використали схему [9], яка грунтувалася на визначенні стадій розвитку молочних залоз, волосся у пахвовій ямці і на лобку, віку настання першої менструації. Всі дівчатка були розділені на три групи - препубертатного (передування появі лобкового волосіння), пубертатного (статеве дозрівання до появи менархе) і постпубертатного періоду (закріплюється пубертатне дозрівання). Таким чином, групу дівчаток пубертатного віку склали 95 школярок, із них 37 дівчаток 5 класу, 18 дівчаток 6 класу, 21 дівчинка 7 класу, 19 дівчаток 8 класу. Всі школярки пубертатного періоду онтогенезу були розділені на групи за календарним віком (повних років): 13 річні - 25 осіб, 12 річні - 33 особи, 11 річні - 17 осіб, 10-річні - 20 осіб.

Антропометричне обстеження було проведено згідно схеми В.В. Бунака [10]. Статистичну обробку отриманих даних проведено 3 використанням параметричних методів статистичного аналізу. 
В результаті проведеного нами дослідження були встановлені середньостатистичні параметри маси, довжини і поздовжніх розмірів тіла у дівчаток різного календарного віку, але які за розвитком вторинних статевих ознак належали до пубертатного періоду онтогенезу. Отримані нами дані демонструють загальну тенденцію до збільшення усіх середніх антропометричних показників фізичного розвитку в дівчаток 3 віком. Ми проводили у дівчаток порівняння відповідних показників попарно між групами порівняння, календарний вік досліджуваних у яких відрізнявся на 1 рік.

Так, довжина тіла у дівчаток різного віку статистично значимо відрізнялася. Суттєві відмінності спостерігалися між групами дівчаток у віці 10 років $(144,1 \pm 3,2 \mathrm{~cm})$ і 11 років $(151,3 \pm 2,4 \mathrm{~cm})$, різниця була достовірною $(\mathrm{p}<0,01)$ та у школярок віком $12(153,1 \pm 6,5 \mathrm{~cm}) \mathrm{i}$ $13(160,5 \pm 3,4$ см) років $(\mathrm{p}<0,001)$. Необхідно зазначити, що у кінці пубертатного періоду онтогенезу у дівчаток спостерігаються найінтенсивніші вікові прирости даного тотального розміру тіла, а у проміжку 3 11 до 12 років - темпи сповільнюються, про що свідчить відсутність достовірної різниці величини даного показника між відповідними віковими групами порівняння.

Нами встановлено, що у дівчаток 10 років маса тіла була $36,12 \pm 5,14$ кг. Достовірні відмінності у масі тіла встановлені між 11-ти $(36,55 \pm 4,66$ кг) та 12 -ти $(41,25 \pm 2,08$ кг) річними дівчатками, а також між 12-ти та 13 -ти $(47,51 \pm 3,07$ кг) річними дівчатками, в усіх випадках $\mathrm{p}<0,01$. Аналізуючи зміни даного тотального розміру тіла, необхідно зазначити, що на початку пубертатного періоду суттєвого приросту маси тіла у дівчаток не спостерігається, не зважаючи на достовірні прирости довжини тіла. А починаючи 312 років починається стрімке збільшення маси тіла. За результатами досліджень окремих науковців відомо, що маса тіла у дівчаток має незаперечливе значення для статевого дозрівання, о особливо кількість жирової маси тіла для настання менархе, тому що в організмі дівчаток підшкірна-жирова клітковина виконує функції депо для накопичення жіночих статевих гормонів, зокрема естрогенів, які впливають на пубертатний розвиток і настання статевої зрілості [9].

Аналізуючи вікову динаміку поздовжніх розмірів тіла необхідно відзначити не синхронність виявлених змін у дівчаток пубертатного віку. Так висота надгруднинної та плечової точок мають аналогічні вікові зміни, про що свідчать встановлені нами достовірні відмінності величини цих двох показників. Так, висота надгруднинної точки статистично значуще відрізняється між дівчатками у віці 11 та 12 років $(\mathrm{p}<0,05)$, та 12 і 13 років $(\mathrm{p}<0,001)$, висота плечової - між 11-ти та 12 річними дівчатками $(\mathrm{p}<0,01)$ та 12 -ти та 13 -річними $(\mathrm{p}<0,001)$. Таким 
чином можна зробити висновок, що найінтенсивніші процеси поздовжнього росту тулуба та нижніх кінцівок, про що свідчить величина цих двох антропометричних параметрів, у дівчаток спостерігається з 11 років.

Таким чином, пубертатний період онтогенезу ми можемо визначити, як комплекс послідовних біологічних стадій, які відображаються і на особливостях антропометричних розмірів тіла, що призводять у подальшому до формування у жінки повноцінної репродуктивної функції.

\section{Література:}

1. Sarafinyuk L. A., Khapitska O. P., Yakusheva Yu. I., Ivanytsia A. O., Sarafinyuk P. V. Somatotypological features of acrobat girls in different periods of ontogenesis. Biomedical and biosocial anthropology. 2018. № 32. P. 43-47.

2. Synovitz L., Chopak-Foss J. Precocious puberty: Pathology, related risks, and support strategies. Preventive Medicine. 2013. Vol. 3. № 9. P. 504-509.

3. Диннік В. О. Сучасні тренди часу старту статевого розвитку дівчат (огляд літератури і власних досліджень). Журнал НАМН Украӥни. 2017. Vol. 23. № 1-2. C. 122-128.

4. Aksglaede L., Sorensen K., Petersen J. H., Skakkebaek N. E. Recent decline in age at breast development: the Copenhagen Puberty Study. Pediatrics. 2009. Vol. 123. № 5. P. 932-939.

5. Дынник В. А. Патоморфоз физического, полового развития и сопутствующей экстрагенитальной патологии у больных с аномальными маточными кровотечениями пубертатного периода за последние 30 лет. Современная педиатрия. 2015. № 1. С. 120-124.

6. Kaplowitz P. Update on precocious puberty: Girls are showing signs of puberty earlier, but most do not require treatment. Advances Pediatrics. 2011. Vol. 58. № 1. P. 243-258.

7. Єременко Г. М., Полька Н. С. Результати вивчення статевого розвитку школярок різних регіонів України. Актуальні питання охорони здоров'я дівчат підлітків. Харків, 1999. С. 51-53.

8. Russo G., Brambilla P., Beffa D. et al. Early onset of puberty in young girls: an Italian cross-sectional study. Endocrinol Invest journal. 2012. Vol. 35. № 9. P. 804-808.

9. Шварц В. Б., Хрущев С. В. Медико-биологические аспекты спортивной ориентации и отбора. М.: Физкультура и спорт. $1984.151 \mathrm{c}$.

10. Бунак В. В. Антропометрия. Практический курс М. : Учпедгиз, $1941.368 \mathrm{c}$. 